\title{
"The evaluation of human computer interface design of learning management systems: problems and perspectives"
}

\begin{tabular}{|c|c|}
\hline \multirow{3}{*}{ AUTHORS } & Wanjiru Gachie ID https://orcid.org/0000-0003-4585-8863 \\
\hline & R http://www.researcherid.com/rid/N-5743-2013 \\
\hline & Desmond Wesley Govender \\
\hline ARTICLE INFO & $\begin{array}{l}\text { Wanjiru Gachie and Desmond Wesley Govender (2017). The evaluation of } \\
\text { human computer interface design of learning management systems: problems } \\
\text { and perspectives. Problems and Perspectives in Management, 15(3), 394-410. } \\
\text { doi:10.21511/ppm.15(3-2).2017.08 }\end{array}$ \\
\hline DOI & http://dx.doi.org/10.21511/ppm.15(3-2).2017.08 \\
\hline RELEASED ON & Wednesday, 06 December 2017 \\
\hline RECEIVED ON & Saturday, 20 May 2017 \\
\hline \multirow[t]{2}{*}{ ACCEPTED ON } & Wednesday, 27 September 2017 \\
\hline & $(c c)$ EY-NC \\
\hline LICENSE & $\begin{array}{l}\text { This work is licensed under a Creative Commons Attribution-NonCommercial } 4.0 \\
\text { International License }\end{array}$ \\
\hline JOURNAL & "Problems and Perspectives in Management" \\
\hline ISSN PRINT & $1727-7051$ \\
\hline ISSN ONLINE & $1810-5467$ \\
\hline PUBLISHER & LLC "Consulting Publishing Company "Business Perspectives" \\
\hline FOUNDER & LLC "Consulting Publishing Company "Business Perspectives" \\
\hline
\end{tabular}

NUMBER OF REFERENCES

45

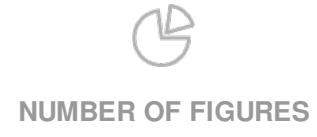

2
NUMBER OF TABLES

6

(C) The author(s) 2022. This publication is an open access article. 


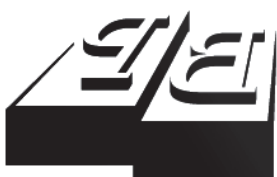

BUSINESS PERSPECTIVES

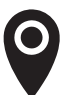

LLC "CPC "Business Perspectives" Hryhorii Skovoroda lane, 10, Sumy, 40022, Ukraine

www.businessperspectives.org

Received on: $20^{\text {rh }}$ of May, 2016 Accepted on: $27^{\text {th }}$ of September, 2017

(C) Wanjiru Gachie, Desmond Wesley Govender, 2017

Wanjiru Gachie, Ph.D., Lecturer, University of KwaZulu-Natal, South Africa.

Desmond Wesley Govender, Ph.D. Associate Professor, University of KwaZulu-Natal, South Africa.

\section{(ㄷ)(1) $(8)$}

This is an Open Access article, distributed under the terms of the Creative Commons Attribution-NonCommercial 4.0 International license, which permits re-use, distribution, and reproduction, provided the materials aren't used for commercial purposes and the original work is properly cited.
Wanjiru Gachie (South Africa), Desmond Wesley Govender (South Africa)

THE EVALUATION OF HUMAN COMPUTER INTERFACE DESIGN OF LEARNING MANAGEMENT SYSTEMS: PROBLEMS AND PERSPECTIVES

\begin{abstract}
With increasing demand for integrating learning management systems (LMS) into teaching and learning, a well-designed LMS is crucial. User interface evaluation has become a critical quality of interactive LMS intended to meet the requirements of users. This article investigates the effect of the interaction on the user and assesses the extent of system functionality. It further seeks to evaluate the interface's success within the framework of fundamental human computer interface principles under a constructivist learning approach. Using an LMS assumes that when learners are engaged in a social learning context they actively construct knowledge; therefore, the resource is considered a tool to support learning and not an end in itself. The research investigates use of the LMS by two sets of users: staff members (module creators) and learners (module consumers), using semi-structured questionnaires and interviews. The research indicates that use of an LMS supports collaborative and authentic activities in learning, serving as an intrinsic motivation to most users. Some problems/concerns that were highlighted included; attention should be given to the tools and elements that should be added to the system, for example the image management tools; some users expressed the desire for more autonomy in terms of the peer review window. It is also recommended that the use of graphics should have a purpose that is either purely functional or contributes more subtly to the page content. Finally, there were requests for more customization of the themes, colors and icons in the design of LMS.
\end{abstract}

Keywords

JEL Classification learning management systems, user interface, system functionality, human computer interaction, teaching and learning, constructivism

I23

\section{INTRODUCTION}

An examination of existing literature shows that the use of learning management systems (LMS) can be as effective as any other method of learning. The appropriate use of LMS increases and creates opportunities for meaningful interactions between course facilitators and the learners (Moore \& Thompson, 2015).

The effective and efficient utilization of the LMS has to commence with a well thought-out strategy and a plan of actions, where the focus is developing a blueprint of the module requirements and the student needs and their cognitive abilities to enhance learning and teaching. A program or system that will yield intended results will require the collaboration and involvement of all the primary stakeholders, namely all the faculty members and the students during all the stages from conception, evaluation to implementation (Gachie, 2003; Amiel \& Herrington, 2012; Software Advice, 2015; Liebowitz, 2016). Evaluation of human computer interface (HCI) is paramount in designing a program that is user centred. The HCI 
seeks to incorporate the human aspects within a system during all the stages from conception, to implementation so that interaction is incorporated (Tognazzini, 2014). For an LMS to serve its intended purpose, $\mathrm{HCI}$ is a major factor to incorporate in the design stage. An earlier study by Gachie (2003) supported the importance of undertaking both formative and summative evaluation of HCI design of LMS.

As a background for this study, the constructivist epistemology was used, wherein the learners are actively engaged in building new knowledge and concepts based upon on the current and historical knowledge. In order to translate theoretical motivation into practice for the evaluation of educational software, this study adopted and threaded together:

- the constructivist epistemology;

- the rich environment for active learning also called REAL environment;

- the user-centred design (UCD) approach; and

- the HCI design principles.

The above four constructs were integrated to form a single reference framework, which was referred to as 'designing by constructivism' model.

In this research perspective, LMS is defined according to Herrington, Reeves and Oliver (2014, p. 402) as content, tasks, problems, collaboration and feedback mediated by a network computer. LMS should foster collaboration among students, which in turn may have a positive effect on students' achievements. Online groups and discussions within an LMS can benefit the learners significantly by involving them in small learning groups, which act as a hub that offers support, reinforcement, motivation and feedback during the learning process. The learner is also motivated, as frequent contact between the learner and the course facilitator is possible.

\section{PROBLEM STATEMENT}

In the last two decades, education has been in the midst of a paradigm shift from an information- processing focus to a constructivist approach to learning. In this research perspective, LMS has been involved in the shift, which is learner-centred, and which is built on the thinking of educational transition upon pedagogical terms such as situated learning, collaboration, scaffolding, authentic activities, and creative thinking (Herrington et al., 2014). The purpose of LMS in teaching and learning process is in the building and reinventing of knowledge, order and reorder knowledge, test it out and justify this interpretation. In essence, the LMS guides both the course facilitators and the learners in unlearning, relearning and learning. A gap exists because there is a dearth in research that examines the evaluation of LMS from a constructivist perspective.

The objective of the article, inter alia, was to examine the HCI aspects of integrating constructivist epistemology in the evaluation of HCI design of LMS. The focus questions are as follows:
1. What are the vital design issues of educational software for supporting the learners and course facilitators in an Internet-based learning environment?

2. How does the utilization of a LMS reflect a paradigm shift (from instructivism to constructivism) with respect to learning and teaching?

\section{THEORETICAL FRAMEWORK \& LITERATURE REVIEW}

\subsection{Constructivist theory}

The theoretical and practical motivation of this research includes emerging pedagogies, concepts and issues related to the creation of an effective learning resource. Exploring the constructivist theory in this research is important, as the theory 
will facilitate comprehension, prediction, control, and the interpretation of 'reality' as constitutes to the usage of a LMS in the learning and teaching process (Athanases \& Oliveira, 2014; Dagar, 2016). Indeed, it is possible to go further and argue that without a theory of some sort, it is impossible to comprehend 'reality' (Marsh \& Storker, 1995; Dagar, 2016). Studies by Software Advice (2015) and Liebowitz (2016) suggest that one of challenges for LMS users is the assimilation of LMS program with other applications such as the desktop computers and smartphones. The essential challenge in using LMS is to improve rather than hinder how individuals work, think, communicate, interact, learn, simulate and express themselves. The purpose of going to a grocery store is to feel satiate. Fuelling the car, the interest is not in buying petrol, but the ability to move from one place to another. Therefore, learners and course facilitators are not pursing the LMS in itself but its ability to perform the intended purpose. Similarly, in designing the LMS, if designers are not careful, they will pursue the wrong things, the thing in itself rather than what the thing can do for the users. In this view, the relationship between HCI principles and constructivist epistemology concentrates on the ability of the users to use seamlessly the LMS for learning, for the transfer of that learning, for the mental representation of that learning, and for enhanced performance.

The constructivist approach is founded on the works of several educational philosophers, which includes John Dewey, Lev Vygotsky, Jerome Bruner, Jean Piaget and Howard Nelson, among others. These educational psychologist have attempted to theorize how teaching and learning takes place by undertaking experiments using example symbols, imageries, illustrations and demonstration in actual settings (Fosnot, 1996; Gachie, 2003, p. 23; Green, 2013; Oulasvirta \& Hornbæk, 2016).

A variety of dimensions can been applied in evaluating educational theories to make a decision on the most appropriate philosophy for a given context. Reeves, Herrington and Oliver (2008) presented these dimensions in 14 different pedagogical dimensions. Some of these are epistemology (objectivism versus constructivism), pedagogical philosophy (instructivism versus constructivism), underlying psychology (behavioral versus cogni- tive), goal orientation (sharply focused versus unfocused), experimental validity (abstract versus concrete), and teacher role (didactic versus facilitative). This article argues that effectiveness of LMS in any learning and teaching environment will depend upon the degree to which the LMS supports a variety of pedagogical perspectives. In particular, the appropriate pedagogy is the one that builds on 'problem-based learning' (Herrington et al., 2014; Oulasvirta \& Hornbæk, 2016), 'social constructivism' (Reeves et al., 2008), and 'communities of practice' (Jonassen, Peck, \& Wilson, 1999; Edutechnica, 2014) literature.

The design of LMS depends on the chosen pedagogical approach (Dalsgaard, 2014). In a constructivist learning and teaching environment, the learners are active participants who are engaged in a variety of activities ranging from problem solving to creative thinking. Central to constructivist pedagogy is the notion that learners and educators are engaged in 'constructing meaning' and in 'negotiating meaning' and coming up with a new meaning. Within any knowledge-building community, the engagement that occurs within an LMS is that of a shared value, whereby each participant brings in something that will be used in the building process.

Therefore, the LMS must incorporate a variety of flexibly available tools that will be used in this knowledge-building process. In so doing, none of the learners will be a parasite but all have an equal opportunity to make a meaningful contribution in coming up with the final product. In such an environment, the tools will make use of a variety of learning styles such as including the use of video, text, audio among others. Moreover, the learning and teaching tools built into the LMS will cater for both a higher and lower order thinking so that all learners will be actively engaged within the REAL environment. These tools will be useful within a social setting of actively engaged learners under the guidance of their course facilitators (Gachie, 2003, p. 50; Brickell \& Herrington, 2008). The tools will cater for a variety of needs such as for the purpose of communicating and discussing ideas, for sharing of tasks and activities, for peer review and giving feedback on assignments online, for support and for interactions among others. 
Tuckman and Monetti (2011) provide a useful model, which adopted in a constructivist environment will enhance teaching and learning. The model proposes that learning is a cyclic process that constitutes of four stages, namely, concrete experience, reflection, abstract conceptualisation, and experimentation, which are relevant within an LMS environment. In this approach, the underlying principle is the belief that knowledge is not separate from but is embedded within experiences, and is interpreted by the learner either in face-to-face learning or within an LMS environment. Within the constructive environment, the learner has an opportunity to select and transform data into meaningful information, construct own hypotheses to be tested by others, and create a new artefact. The learner does so by relying on cognitive structures and by interacting with the physical and social world.

Piaget's proposal of cognitive structures in the form of schema and mental models provide meaning and organization for experiencing and allowing the users to go beyond the information given within a social context (Tuckman \& Monetti, 2011). Thus, the LMS provides a context for association, for assimilation, for accommodation and for adaptation of knowledge. The desire is for the learners to move from lower to a higher order thinking and ultimate get into higher plane of becoming creators.

The purpose for the LMS is then to provide an opportunity to empower the learners by the use of the various tools incorporated (Dalsgaard, 2014, p. 5). The LMS will serve the purpose of serving the course facilitators in their efforts of providing for discover learning, which Bruner (1990, p. 29) refers to as 'Socratic learning'. The LMS will also assist the course facilitators to provide an environment for spiral 'curriculum' rather than providing for a hierarchical 'curriculum' that is rigid and inflexible. A spiral 'curriculum' is branched in nature, flexible and allows for discovery learning, an excellent hub for knowledge construction Bruner (1990, p. 29; Gachie, 2003, p. 60).

The LMS places social constructivist teaching and learning at the centre which enhances a paradigm shift so that the mind, the thinking process is brought into the authentic activities, which over- all determine the results. Within the social constructivist, teaching and learning the learners are creators and designers within the LMS engaged in problem solving and creative thinking. The purpose of the LMS is to offer a platform for the learners to build their own 'new' knowledge by testing their previous knowledge against the tasks and activities provided by the course facilitators.

\section{2. $\mathrm{HCl}$ design principles}

HCI design principles involve the exchange, collaboration and sustaining of relationships between humans and computers. A computer without the human aspects is therefore seen a useless product, only to be used for aesthetic purpose and not to serve the users. HCI is a multidisciplinary field covering many areas, all having a different focus depending on a disciplinary point of view. In the first 10 to 15 years, the study and the incorporation of HCI has focused on user interfaces, particularly on the potential of a system to meet agreed criteria which includes graphics, download, consistency, and readability (Dix, 2016). According to Tognazzini $(2014$, p. 6$)$ "If ease of use was the only valid criterion, people would stick to tricycles and never try bicycles". Overall, the HCI aspects of a program serves to validate its purpose. The important thing is not to design a product not only for that sake, but also on how to use the system to achieve the intended use. Therefore, HCI aspects are there to empower the users to becoming into whom they are meant to become and not just a resource offered as an additional tool in teaching and learning. Incorporating $\mathrm{HCI}$ aspects offers the users a better way of learning. The LMS is not a problem or a hindrance to teaching and learning but is to offer liberty not to do as the users please but to be empowered into becoming creators and designers of their own learning path and of their artefacts. The LMS through HCI is a resource that serves the users and not vice versa. It is a servant and not a master in the learning process. Individuals drive their vehicles with the intention not to drive but to get from point A to B. In this case, the LMS in itself is a means to an end and it not the end in itself. Therefore, the LMS facilities are in empowering the learners to become those the course facilities intend them to become. The $\mathrm{HCI}$ aspects are there to ensure that the intention 
of the LMS is clear and valid. Through incorporating $\mathrm{HCI}$, the power is transferred to the learners and the course facilitators and not on the system itself.

Several authors in the HCI literature have proposed guidelines and models for incorporating HCI design features (Vassiliou, 1982). In designing educational software, the goal is to produce a learning resource that is both fun and educationally beneficial. Assigning print strategies to a web layout is disastrous in web design, because many of the rules of print simply would not apply to the web. In essence, there is no one universally accepted measurement of a system such as LMS. The qualities of measuring the HCI aspects will determine the 'acceptability', the 'appropriateness' and 'usability' of that product (Nielsen, 2013). Therefore, a designer is at liberty to come up with a mix of indicators and criterion that should be derived from the generally accepted HCI design principles. A designer can also use existing benchmarks and standards, as well as adopt the measurement used by successful predecessors in the HCI industry.

The evaluation of HCI features of a system illustrates the importance of designing LMS that revolves around the users. This means the designer will have an image of the users in mind at all times from conception into implementation, so that a usable product will emerge that is centred around HCI design principles (Gachie, 2003, p. 41; Oxagile, 2016, pp. 1-4). Nielsen (2000, 2013) suggests the following components:

- Utility. This is will determine how well the system serves its intended purpose. Utility has to do with utilization of a product. Utility determines the state of the LMS being useful, being profitable and offering benefits to the users. An antivirus software is a utility that gives the users a peace of mind because of the knowledge that their application are protected from viruses. The purpose of the antivirus software is not to slow down the running of the applications. Thus, the utility will be determined by performance, by functionality of the LMS and fitness, in terms of how well the interface is integrated into the learning and teaching process. Functionality is more important than at- tractiveness. The LMS should be as seamless as possible so as not to hinder learning and teaching.

- Effectiveness. This will determine the degree to which the LMS is successful in producing the result desired by the users. Effectiveness will also be measured by extent to which problems that occur are resolved. The lower the failure and error rates of the LMS the better it will be perceived. The quicker the users are able to complete their tasks and activities using the LMS the more effective. Users will determine how effective the LMS is by its completeness and accuracy while using the system. The Effectiveness of the system can be affected by the presence of bugs and errors.

It is vital to evaluate LMS from different perspective of usability and HCI design principles ranging from incorporating education management, system hardware and software, courses and documentation (Dalsgaard, 2014; Mathewson, 2015; Stone \& Zheng, 2015; Oxagile, 2016). Nielsen $(2000,2013)$ also discusses other important principles, which are summarized below.

- Memorability. The ease with which the users will be able to remember a process that they previously performed using the LMS will be determined by its memorability. The users perception of the LMS will determine whether they consider it worthwhile to remember how to perform a certain task. The mind then is a collection of the memories (a container), and the users actions are the outcome of the mind. The fewer the steps to be remembered, the higher the users perception will be, which will consequently affect effectiveness and learnability.

Errors. The LMS perceived a mistake by the users affects its credibility. The users will subjectively assign a measure of the difference between the observed and the true value of the LMS based on the errors encountered. The higher the perceived deviation from being accurate or correct, the lower the acceptance rate. The lower the error rate, the higher the acceptance rate, also known as the error pre- 
vention principle. Error messages should indicate the cause and/or the cure for the error.

- Readability. This is determined by the quality of the LMS being legible or comprehensible, which affect the ease of use and the enjoyment in reading. Readability of the text will depend on the content, the complexity of terminology and syntax and on the mode of presentation, such as typography aspects like font type, size, line spacing, height, and length of each line. Thus, designers should give consideration to:

- The resolution of a display monitor is the total number of pixels used to display the picture. A pixel is a single dot of light on a display monitor. The more pixels used, the better the resolution and therefore the quality of the graphics (Austin, 2001; Green, 2013).

- Typography. The harsh reality of web design is that a designer does not have the kind of control over how the text appears as would a print designer. Font style and size, where the text breaks and how the text reads are all aspects of typography (Nielsen, 2013).

- Graphics. Another important principle in the $\mathrm{HCI}$ literature is the appropriate use of graphics in educational resources. It is best to keep download time as short as possible. This can also affect the Internet connectivity costs for distance learners. Images can be used to add some content, style or interest to a site; however, they should be appropriate to the content of the page and fit with the colour scheme, among other things (Tognazzini, 2014).

- Navigation and hyperlinks. A link is a connection from one page to another within one website (on-site) or other websites (off-site) that are important or interesting for the viewers. 'Navigation' is the process of clicking on the links that assist the viewer in moving from one page to another within a website. Good links facilitate navigation. They can be textual or graphic. Navigation is one of the most important elements in designing a good learning resource (Tognazzini, 2014).
Consistency. This refers to the mode in which the patterns are perceived to be similar as they perform their tasks and activities and during interaction with the system. How well the LMS holds together will affect the users in terms of being efficient and the effectiveness of the system. The LMS being consistent means that each of the pages will stay the same, a task will be done in the same manner and each page will look similar. In being consistent the LMS will remove the burden of human learning and relearning how to use the application because of the increased ability recognize patterns and in the presentation a familiarity in configuration. All graphic images and elements, typefaces, headings, navigation, background footers and special effects should remain consistent throughout the LMS (Tognazzini, 2014; Mathewson, 2015). Tables can be used to enhance consistency. An HTML table is a grid of cells laid out in rows and columns. Each table cell can contain text, numerical data, an image or even another table.

- Learnability. This will determine the quality of the LMS and associated interfaces that with respect to how quickly the users will gain familiarity. The learnability aspect will also determine the users' ability to make good use of all the LMS capabilities and associated features. A well-grounded LMS should be user-friendly and not a product that requires rigorous learning and relearning in order to accomplish its purpose. Learnability will be a matter of users' perception in terms of error rates, the time it takes to get familiar with the LMS. Learnability will also determine the ability to complete a task effortlessly and in a timely manner, the ability of the LMS to operate effectively and efficiently, the ability to correctly recall and the ability to increase in learning (Nielson, 2000, 2013; Gachie \& Govender, 2015).

- Metaphor. This will determine how well the designers will make use of commonly used words to represent an icon or a task on the LMS. The ability to make excellent comparisons in the place of another thing will increase the learnability of the users. The analogy of a runner as icon to represent a discussion forum icon can be considered as confusing and inappropriate. Tognazzini (2014) notes that metaphors select- 
ed with diligence enhance the users' ability in effective and efficient use of the system. Thus, it can be argued that the better the metaphor or analogy, the better the users imagination will be, and the higher the learnability.

The application of HCI design process is an iterative process, essentially incorporated in the overall product design. In essence, HCI should be considered at all product stages; conception to implementation and evaluated on a constant basis in order to avoid surprises (Nielson, 2013; Edutechnica, 2014).

The principles thus outlined work in harmony, because the absence of one will negatively affect the overall performance and desirability of the LMS. Incorporating $\mathrm{HCI}$ in the evaluation of the LMS was therefore critical in determining the extent to which the system adhered to the principles in terms of functionality, users' comprehension, appropriateness, and in meeting user requirements.

\subsection{Proposed model: designing by constructivism}

A 'designing by constructivism' model has been prepared for this study as an improvement of earlier model in Gachie (2003, p. 58) as shown in Figure 1. The reason for focusing on social constructivism is because it is centred on a social perspective to learning rather than an individualist perspective. The model further builds on aspects of REAL environments to describe a learning interface of an integrated evaluation process. The model mainly describes a process of social interactions, as stated in Vygotsky's work, the UCD approach and HCI principles.

The social constructivism is based on the works of Les Vygotsky $(1962,1978)$, which considers the role of language, culture, collaboration, support, scaffolding in teaching and learning. The social aspects of learning as described by social constructivism is to be considered as useful for those seeking to design educational projects that result in meaningful learning. The designing by constructivism model (Figure 1) is observed as an implementation of the social constructivist perspective, as many of the aspects of social aspects of learning are present in this model. One of the basic assumptions of Vygotsky's framework is the creation of a social learning environment (Fosnot, 1996; Oxagile, 2016). Therefore, designing a learning environment with a combination of different computer-mediated communication (CMC) tools is desirable.

\subsection{User-centred design approach}

The User-centred design (UCD) approach is necessary in evaluating the effectiveness of the LMS to make ensure the users involvement from conception to implementation. The intended use and purpose of the system can only be determined as

\section{Online learning}

UCD
(Pedagogical issues)
Models of REAL
(Computer-mediated communication tools to facilitate learning)
(Authentic learning context)
Constructivism
(Social perspective)
Teachers' identities - course facilitating, guiding and scaffolding
$\mathrm{HCl}$ design principles
(Readability, navigation and consistency)

Figure 1. Designing by constructivism model created by the author intended for this research 
judged by the users. The LMS users can offer suggestions during the system cycle in terms of their needs, or requirements and offer critical background information that relates to their strengths, limitations and behaviors, which will aid in system design (Gachie, 2003; Herrington et al., 2010; Gachie \& Govender, 2015). The designers will have to make use of several data collection methods namely qualitative and quantitative to determine user requirements and undertake testing of the prototype before fully implementation. In addition, the user-centred software design approach will require the testing user satisfaction after they have engaged with the system for a set period to gather data and feedback, which will be useful in making improvements and updates.

\subsection{REAL}

REAL environments can be viewed as those that allow for different learning styles, those that allow for collaboration and authentic activities, and those that allow for interaction, for example, CMC tools. Authentic learning is used in this article as one of the aspects of REAL environment. An authentic context provides a meaningful and situated and anchors learning to real world (Ashford-Rowe, Herrington, \& Brown, 2014). REAL provides the learners with a context to solve problem that occur naturally or study cases that were recorded from events.

In this study, REAL is a term that comprises four terms, namely providing a (i) Rich (ii) Environment for (ii) Authentic or Active (iv) Learning. In REAL environment, the learners assume the responsibility and initiative to learn in an authentic learning context where the assessments are seamlessly integrated (Amiel \& Herrington, 2012; Makewa, Kuboja, Yango, \& Ngussa, 2014). The use of LMS will therefore provide with a social platform for these intrinsically motivated learners to engage in creating meaning. In the discussion of REAL, environments are those that allow for collaboration and those that allow for authentic activities. Relating the designing by constructivism model to REAL is very important, as these environments have attributes that make them an excellent choice for acquisition of transferable knowledge.
Similarly, integrating the social constructivism and the REAL model in considering the HCI design principles was deemed as a prerequisite for the LMS to be successful in achieving the intended purpose. The LMS was aimed at scaffolding the learners into becoming authentic learning experiences immerse the learner in a culture, much like an apprenticeship (Young, 1993; Ellis \& Calvo, 2007; Athanases \& Oliveira LCD, 2014; Mathewson, 2015). These types of activities reflect the experiences of real-world practitioners, which may assist student learners to transfer knowledge into real-world settings. Students can be assisted in this complex learning environment by providing them with online samples of past projects, employers' perspectives and server space for hosting their projects.

Incorporating a REAL environment in the design of the LMS will require equipping the designers with a basic knowledge of the essential features of authenticity (Gachie, 2003; Herrington et al., 2014, pp. 34-37; Gachie \& Govender, 2015). An effective LMS allows for the completion of ill-defined tasks and activities. The LMS provides opportunities for students to examine the task from different perspectives, using a variety of digital media and applications. The LMS provide a platform for collaboration and interaction and for incorporation of various types of assessment strategies and types during the teaching and learning process (Athanases \& Oliveira LCD, 2014; Herrington et al., 2014, pp. 34-37; Gachie \& Govender, 2015; Dagar, 2016).

Although it is almost impossible to design an LMS that truly incorporates all the aspects of a REAL environment, it is nevertheless possible for designers to ensure that they consider abovementioned features. In so doing, they will increase the acceptability of the LMS by a range of stakeholders.

Consumer awareness is on the rise during the last decade and the users expectations are on the increase that call designers to consider all important aspects before implementing LMS (Green, 2013; Stone \& Zheng, 2015; Oxagile, 2016). For example, designers can consider the effect of social networks as powerful computer-mediated communication (CMC) too that offer opportunity for REAL environment. Also designers should consider the 
potential that is offered by cloud computing and thus utilise such opportunities in providing users with the ability to share tasks, activities and learning experiences seamlessly as input, storage, output and routing devices collaboratively notwithstanding location (Alexander, 1999; Gachie, 2003; Gachie \& Govender, 2015). However, there have been continued debates on whether media influences learning. For example, Clark (1994, pp. 21-29) argues that "Media does not influence learning under any conditions... media is merely a vehicle that deliver ... but do not influence student achievement any more than the truck that delivers our groceries causes changes in our nutrition".

Gachie and Govender (2015), Green (2013), Edutechnica (2014) and Dalsgaard (2014) demonstrate the importance of incorporating social communication tools and strategies in LMS. In this research, asynchronous communication such as email, bulletin boards or newsgroups provide time for reflection and composition. The adoption of synchronous communication tools is essential so that learners and course facilitators can be engaged seamlessly and instantly in the mutual process of knowledge sharing and creation. Collaboration activities are enhanced during synchronous communication with the aid of a variety of digital media tools such as text chat, audio and videoconferencing, and the use of online whiteboards, all which are critical CMC components that should be part of the LMS.

\section{METHODOLOGY}

Based on the proposed research questions, a mixed methods approach was adopted for this study. An analysis of over 20 definitions reveals a strong agreement that mixed research involves the application of both quantitative and qualitative methods within a single research. Mixed-method research is has been supported by scholars and researchers including Creswell (2015), Ivankova, Creswell and Plano-Clark (2007), Creswell and Plano-Clark (2011), Onwuegbuzie (2014). Onwuegbuzie and Benge (2014), McMillan and Schumacher (2011, p. 110), Ivankova et al. (2007, p. 3) justify the use of a combination of methods by arguing that "the rationale for mixing both kinds of data within one research is grounded in the fact that neither quantitative nor qualitative methods are sufficient, by themselves, to capture the trends and details of a situation".

\section{RESEARCH INSTRUMENTS}

This study adopted a questionnaire using similar instruments developed by Tuckman (1979). The questionnaire was divided into four sections that comprised of a statement followed by a choice of four possible responses. In total, 34 questions were created using a four-point Likert scale. The score of 1 and 2 was seen as negative response ('Disagree'), while 2 and 4 was seen as a positive response ('Agree'). Lastly, a section to fill in comments and suggestions was provided.

There were four main objectives with the questionnaire. The first objective was to find out the users' reflections, feelings and attitude towards the use of an LMS; the second to investigate users' perception of the quality of the LMS resource; the third to establish the tools and elements that users viewed as important in an LMS; and the fourth to determine the overall users' perceptions and attitudes towards the LMS which included problems and concerns.

The number of respondents included 5 academic staff and 38 learners, 30 of which were secondyear undergraduate Biology students undertaking a course called 'Protein, structure and function'. These students were studying using a mixed method learning and teaching approach, which entailed both a face-to-face interaction in combination with an online teaching and learning setting. The remaining 8 learners were Honours and Master's students in the field of Digital Media who were undertaking four modules on purely online setting with minimal face-to-face interaction with the course facilitators.

In-depth face-to-face interviews using open-ended, non-leading questions were used. This type of interview is suitable for this study, which deals with users' perceptions. The users were selected to participate in the interviews after giving informed consent. Users were asked to describe their relevant activities. 'Why' questions were asked to 
get to the major goals, and 'How' questions were asked to get to the details of actions in accomplishing the users' objectives.

A total of 20 users, four course facilitators (module creators) and 16 learners (module consumers) participated in the interviews. These participants were chosen using purposeful sampling on a volunteer basis. Appointments were made with the interviewees and they were interviewed individually. These interviews were conducted at different venues, at the convenience of each participant.

\section{RESULT AND DISCUSSION}

\subsection{Findings from the questionnaire}

\subsubsection{Design of the resource}

The purpose of this section was to address the users' reflections and feelings about the use of LMS design. The main aim was to identify issues revolving around navigation, the use of computer terminologies, language and syntax, error received and perceived and the ability to memorise or remember how to use the LMS, as shown in Table 1.

Table 1. Percentage (rounded) frequencies of users' responses to design descriptions

\begin{tabular}{|c|c|c|}
\hline \multirow{2}{*}{ Description } & \multicolumn{2}{|c|}{ Percentage } \\
\hline & Agree & Disagree \\
\hline $\begin{array}{l}\text { Navigating between the pages was not } \\
\text { difficult }\end{array}$ & 76 & 24 \\
\hline $\begin{array}{l}\text { Computer-related terms were } \\
\text { appropriately used }\end{array}$ & 86 & 14 \\
\hline $\begin{array}{l}\text { The error messages were clearly } \\
\text { understood }\end{array}$ & 60 & 40 \\
\hline Using the resource was not difficult & 89 & 11 \\
\hline $\begin{array}{l}\text { Login into the resource was done with } \\
\text { ease }\end{array}$ & 69 & 31 \\
\hline $\begin{array}{l}\text { Appropriate authentication and } \\
\text { security features were present }\end{array}$ & 75 & 25 \\
\hline $\begin{array}{l}\text { Navigation was well presented and } \\
\text { logical }\end{array}$ & 76 & 24 \\
\hline $\begin{array}{l}\text { The tools used support my learning } \\
\text { style }\end{array}$ & 70 & 30 \\
\hline Learning new features was not difficult & 74 & 26 \\
\hline $\begin{array}{l}\text { The human memory and ability to } \\
\text { remember were considered }\end{array}$ & 85 & 15 \\
\hline $\begin{array}{l}\text { The language, syntax and format used } \\
\text { was well expressed }\end{array}$ & 90 & 10 \\
\hline $\begin{array}{l}\text { The resource encouraged ability to } \\
\text { collaborate and interact }\end{array}$ & 90 & 10 \\
\hline
\end{tabular}

The findings indicate that implementing educational software in an actual system requires that designers comprehend the users' needs, the intended purposes for which they the LMS was to be used, the users' needs and prior knowledge, and their background knowledge. Based on the designing-by-constructivism model and theoretical aspects of designing, it emerged that the system met most of the design principles that should be found in a good interface, for example, the use of color and graphics, navigation, and consideration of human memory limitations.

\subsection{Learning resource attributes and elements}

The purpose of this section was to find out the tools and elements that users found to be important, as shown in Table 2.

Table 2. A percentage (rounded) frequency scores of users' responses to statements regarding the learning resource attributes and elements

\begin{tabular}{l|c:c}
\hline \multirow{2}{*}{ Element } & \multicolumn{2}{c}{ Percentage } \\
\cline { 2 - 3 } & Agree & Disagree \\
\hline Email & 79 & 21 \\
\hline Appointments and tasks & 66 & 34 \\
\hline Calendar & 62 & 38 \\
\hline My modules & 97 & 3 \\
\hline Discussion forum & 90 & 10 \\
\hdashline Chat & 71 & 29 \\
\hdashline Icons & 76 & 24 \\
\hdashline Customization themes & 79 & 21 \\
\hline
\end{tabular}

The users agreed that the CMC tools, especially asynchronous tools, allowed them to reflect as they participated in communication processes. It is very interesting to note that the system is designed in such a way that it can be used in both a mixed mode of learning and in purely online learning.

\subsection{The resource attributes and elements important in an LMS}

The purpose of this section was to find out the tools and elements that users found to be important in the use of an LMS in learning and teaching, as outlined in Table 3 . 
Table 3. Percentage (rounded) frequency scores of users' responses to statements regarding the learning resource attributes and elements

\begin{tabular}{l|c:c}
\hline \multirow{2}{*}{ Element } & \multicolumn{2}{c}{ Percentage } \\
\cline { 2 - 3 } & Agree & Disagree \\
\hline Email & 79 & 21 \\
\hline Appointments and tasks & 66 & 34 \\
\hline Calendar & 62 & 38 \\
My modules & 98 & 2 \\
\hline Discussion forum & 90 & 10 \\
\hdashline Chat & 71 & 29 \\
\hline Icons & 76 & 23 \\
\hline Customization themes & 79 & 21 \\
\hline
\end{tabular}

The results in Table 3 indicate the users' appreciation and acceptance of the tools and elements in the LMS. However, the percentages vary greatly. The first tool under investigation was email, an asynchronous CMC tool, where $79 \%$ of the respondents agreed and $21 \%$ disagreed that it is an important CMC tool.

\subsection{Overall design}

This section addressed the users' general and overall opinions of the use of the LMS presented in Table 4.

Table 4. Users' responses to statements regarding the overall LMS design

\begin{tabular}{l|c:c:c}
\hline \multirow{2}{*}{ Overall design } & \multicolumn{2}{c}{ Percentages (rounded) } \\
\cline { 2 - 4 } & Agree & Disagree & $\begin{array}{c}\text { Missing } \\
\text { values }\end{array}$ \\
\hline Learning the operations & 86 & 14 & 0 \\
\hline Human memory limitations & 86 & 14 & 0 \\
\hline $\begin{array}{l}\text { Use by different levels of } \\
\text { experience }\end{array}$ & 79 & 21 & 0 \\
\hline Metaphor use & 61 & 37 & 2 \\
\hline Overall displays & 57 & 40 & 3 \\
\hline Exploration of features & 81 & 17 & 2 \\
\hline The overall resource & 86 & 14 & 0 \\
\hline The overall reactions & 80 & 20 & 0 \\
\hline
\end{tabular}

Generally speaking, the positive responses on these questions are high. From the quantitative analysis, $61 \%$ of respondents agreed that the metaphor was appropriate, while $37 \%$ disagreed. Following further investigation using qualitative data analysis, it emerged that those users who disagreed did not comprehend or perceive the meta- phor used, while others were not accustomed to this kind of learning concept, hence the need for online documentation. The findings further indicate that information presentation is a very important attribute in a learning resource. The reason for this is that the way information is presented affects readability, among other things. Examples of good presentation characteristics include page layout, typography and color schemes.

\subsection{Results from the interviews}

Extraction of the qualitative results was aided by the use of NVivo, a computer software package for qualitative analysis. The audio-recorded interviews were transcribed and the texts were saved in rich text format and imported to NVivo for analysis. This facilitated the extraction of interesting themes.

\subsection{Experiences users had with the LMS}

This section presents the users' experiences with the resource, which were determined by asking seven structured questions in an attempt to find out the degree of user-friendliness of the interface; the features they liked or disliked most about the resource; the improvements or changes they would wish to be made on the resource; their perception of learning as part of a collaborative group; their perception of LMS as an online learning resource; and the features of the resource that they felt could be substantially simplified.

Qualitative analysis determined a number of positive themes, including transparency in the language and syntax used; the appropriate use of graphics; provides an opportunity for interaction and collaboration within the system; overly consistent; strong customisation ability; very strong navigation; and strong learning tools, for example, the chat, discussion forum and peer review tool. More insights on this were gained during the qualitative results analysis, where, for example, some users expressed the desire to be able to use their own icons and to have more control over the peer review tools, such as reviewing articles offline and saving articles on disk. 


\subsection{Use of LMS in a social constructivist setting such as a collaboration or group}

The aim of this section was to find out how much the resource has achieved or would achieve in terms of collaborative learning and interactions, which is a very important aspect in social constructivism. The participants found this question to be very important, as they agreed that the use of an LMS is grounded on such principles, which they use in undertaking some of the Biology projects. Therefore, they saw themselves as being involved in collaborative learning.

\subsection{Users' perception of LMS as an online learning resource}

The users' perception of using an LMS as an online learning resource is presented in Table 5, which outlines the tools and elements that users appreciated, and their contribution towards learning and teaching. All the users interviewed agreed that LMS was a suitable online learning resource. One interesting theme that emerged because of the responses given to this question was that the participants felt that the LMS was well- built and, hence, designed to offer a high quality and interactive teaching and learning environment seamlessly.

From Table 5, it can be concluded that an LMS has been built with an integration of scaffolding features and has utilized the design principles and processes which can offer support for web-based courses. Some examples of key indicators of scaffolding in the LMS are the provision of learning tools to help the learners solve and share their problems with others; and the multiple CMC channels that are integrated in the resource to enable discussion, conversation and exchange of ideas.

\subsection{Additional tools and elements users would like added in an LMS}

This section aimed to identify any additional tools and elements that users would like added into an LMS for enhanced learning and teaching, as outlined in Table 6 . This was done by asking them which tools they thought should be added into an LMS, and why.

Table 5. Tools and elements that users appreciated, and their contribution towards learning

\begin{tabular}{|c|c|c|c|}
\hline Tool/element & General perception and contribution of each & $\begin{array}{l}\text { Scaffolding afforded } \\
\text { by the tools }\end{array}$ & $\begin{array}{l}\text { No. of } \\
\text { users }\end{array}$ \\
\hline Chat & $\begin{array}{l}\text { The synchronous nature provided for a high degree of real- } \\
\text { time interaction }\end{array}$ & Online mentoring & $15 / 20$ \\
\hline Discussion forum & $\begin{array}{l}\text { Asynchronous nature provided for reflective thinking, } \\
\text { exchanging of views and ideas and collaborative learning }\end{array}$ & $\begin{array}{l}\text { Guided reflection and } \\
\text { online mentoring }\end{array}$ & All \\
\hline Peer review & $\begin{array}{l}\text { Provided for critic, improvement of work in preparation for } \\
\text { portfolio submission and for collaboration }\end{array}$ & $\begin{array}{l}\text { Peer support and online } \\
\text { mentoring }\end{array}$ & $14 / 20$ \\
\hline $\begin{array}{l}\text { Hyper-linked access to } \\
\text { courses }\end{array}$ & $\begin{array}{l}\text { Provided for easy and organized access and navigation of } \\
\text { courses and online resources to the users }\end{array}$ & $\begin{array}{l}\text { Sharing resources and } \\
\text { self-regulated learning }\end{array}$ & All \\
\hline Customization themes & $\begin{array}{l}\text { All the users commended the resource for the customization } \\
\text { capabilities }\end{array}$ & $\begin{array}{l}\text { Flexibility and user } \\
\text { control }\end{array}$ & $13 / 20$ \\
\hline Appointment and tasks & $\begin{array}{l}\text { There were mixed feelings towards this tool; some viewed it } \\
\text { as a very important tool for managing their electronic diary, } \\
\text { while others did not find it to be necessary }\end{array}$ & - & $7 / 20$ \\
\hline Email & $\begin{array}{l}\text { The integration of the email facility with the existing email was } \\
\text { found to be very important for collaboration and the exchange } \\
\text { of ideas }\end{array}$ & $\begin{array}{l}\text { Guided reflection, peer } \\
\text { support and online } \\
\text { mentoring }\end{array}$ & $16 / 20$ \\
\hline $\begin{array}{l}\text { Document management } \\
\text { tool }\end{array}$ & $\begin{array}{l}\text { All the four course facilitators liked the document } \\
\text { management feature, which allowed them to manage their } \\
\text { files }\end{array}$ & Sharing resources & $4 / 4$ \\
\hline
\end{tabular}


Table 6. Various tools and elements that users suggested should be added

\begin{tabular}{|c|c|c|}
\hline Tools/elements & Reasons & Illustrative quotations \\
\hline Whiteboard & $\begin{array}{l}\text { Seven users felt that it would } \\
\text { be a good idea to add more } \\
\text { collaborative and visual tools }\end{array}$ & $\begin{array}{l}\text { "... A persistent whiteboard. This is a whiteboard equivalent of } \\
\text { the discussion list, where you can go to a whiteboard area, put } \\
\text { an image on and add some annotations, and when you log out it } \\
\text { says there for some time" } \\
\text { "... More collaborative and visual tools ... like the video } \\
\text { conferencing and people to draw things visually and represent } \\
\text { their knowledge visually and collaborate on it ... Persistent } \\
\text { whiteboard ..." }\end{array}$ \\
\hline Image management tool & $\begin{array}{l}\text { Three users expressed interest in a } \\
\text { graphic management tool }\end{array}$ & $\begin{array}{l}\text { "Certainly I would say something around graphics" } \\
\text { "An image management tool ... as images are important in } \\
\text { learning" }\end{array}$ \\
\hline $\begin{array}{l}\text { Log-off button from } \\
\text { resource }\end{array}$ & $\begin{array}{l}\text { Two users expressed a lot of } \\
\text { interest in having a log-off } \\
\text { button, as in the case of the email } \\
\text { application }\end{array}$ & $\begin{array}{l}\text { "...There is no option to log out, maybe a little button that says } \\
\text { log out' and after that a page that says that you are now logged } \\
\text { out ..." }\end{array}$ \\
\hline New postings button & $\begin{array}{l}\text { One user felt the need for a new } \\
\text { posting button }\end{array}$ & $\begin{array}{l}\text { "... A tool that allows a course facilitator to see, on the front page, } \\
\text { whether there are new postings, instead of entering into each } \\
\text { course that you are facilitating to check for new postings" }\end{array}$ \\
\hline Search engine & $\begin{array}{l}\text { One user wanted the system to } \\
\text { have a search engine }\end{array}$ & $\begin{array}{l}\text { "A search engine, probably, one that is advanced and specifically } \\
\text { geared to this kind of learning" }\end{array}$ \\
\hline $\begin{array}{l}\text { More user-control } \\
\text { abilities }\end{array}$ & $\begin{array}{l}\text { Ten users expressed an interest in } \\
\text { more user-control functionality, } \\
\text { for example, for working off-line, } \\
\text { a minimize button, and ability for } \\
\text { students to change some of their } \\
\text { details }\end{array}$ & $\begin{array}{l}\text { "... On article review, the paper evaluations, there are students } \\
\text { who work from home, if they ... can save these articles and work } \\
\text { from home. The other problem is that one cannot minimise" } \\
\text { "I would like the students to be able to change their user profiles, } \\
\text { for example, where we have given name and preferred name, I } \\
\text { don't know the students preferred name ... However, this does } \\
\text { not mean they change other things like student number" }\end{array}$ \\
\hline $\begin{array}{l}\text { More student } \\
\text { management capabilities }\end{array}$ & $\begin{array}{l}\text { Some of the course facilitators } \\
\text { wanted to see easy student- } \\
\text { creation capabilities }\end{array}$ & $\begin{array}{l}\text { "What I hope to see with the LMS is where I shall be able } \\
\text { to upload from the university system soon. Uploading } 90 \\
\text { students one at a time is a bit of a slump, I have to modify the } \\
\text { spreadsheets that are produced ... takes me a lot of time ... That } \\
\text { part I think can be streamlined" }\end{array}$ \\
\hline $\begin{array}{l}\text { A spell checker and } \\
\text { audio files }\end{array}$ & $\begin{array}{l}\text { One user expressed an interest } \\
\text { in this }\end{array}$ & $\begin{array}{l}\text { "A spell checker and audio files; as digital media students we may } \\
\text { want to demonstrate something and share with peers, therefore, } \\
\text { it should accommodate multimedia and also be able to run spell } \\
\text { checking" }\end{array}$ \\
\hline $\begin{array}{l}\text { On-screen user } \\
\text { identification }\end{array}$ & $\begin{array}{l}\text { One user expressed the need for } \\
\text { a personalized identity display on } \\
\text { the LMS homepage }\end{array}$ & $\begin{array}{l}\text { "... If the student can be identified by system, for example, by } \\
\text { their student numbers or names" }\end{array}$ \\
\hline
\end{tabular}

\section{DISCUSSION OF INTER- VIEW RESULTS}

The results indicates that a high degree of user fulfilment with LMS. Overall the participants are satisfied with their ability to use the LMS, noting that the system was user friendly.

The third research question related to the important features and tools that should be integrated in learning software. The features and tools that users felt should be added into the system are listed in Table 6. In summary, these are a whiteboard, an image management tool, a log-off button, a new posting button, a search engine, more user-control capabilities, more student management capabilities, a spell checker, and on-screen user identification. Similarly, the tools that they appreciated are outlined in Table 5.
From the interviews conducted, the three stages of learning described by Bruner (1990) (enactive, iconic and symbolic mode) have aided the users in relating the use of an LMS to other computer environments. Most of the users learnt how to use the resource through trial and error, which can be related to Piaget's cognitive constructivist philosophy of assimilation and accommodation leading to adaptation. An enhanced graphic framework of the designing by constructivism model with elements similar to those in Figure 1 was constructed using NVivo, as shown in Figure 2. The model further assisted with developing, considering and recording thoughts about different concepts and their relationships. Construction of the same model in two different formats and stages allowed for further reflections, and the issues under investigation became clearer each time. 


\section{DESIGNING-BY-CONSTRUCTIVISM MODEL}

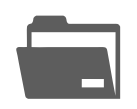

(1) $\mathrm{HCl}$ design

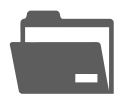

(2) User-centered

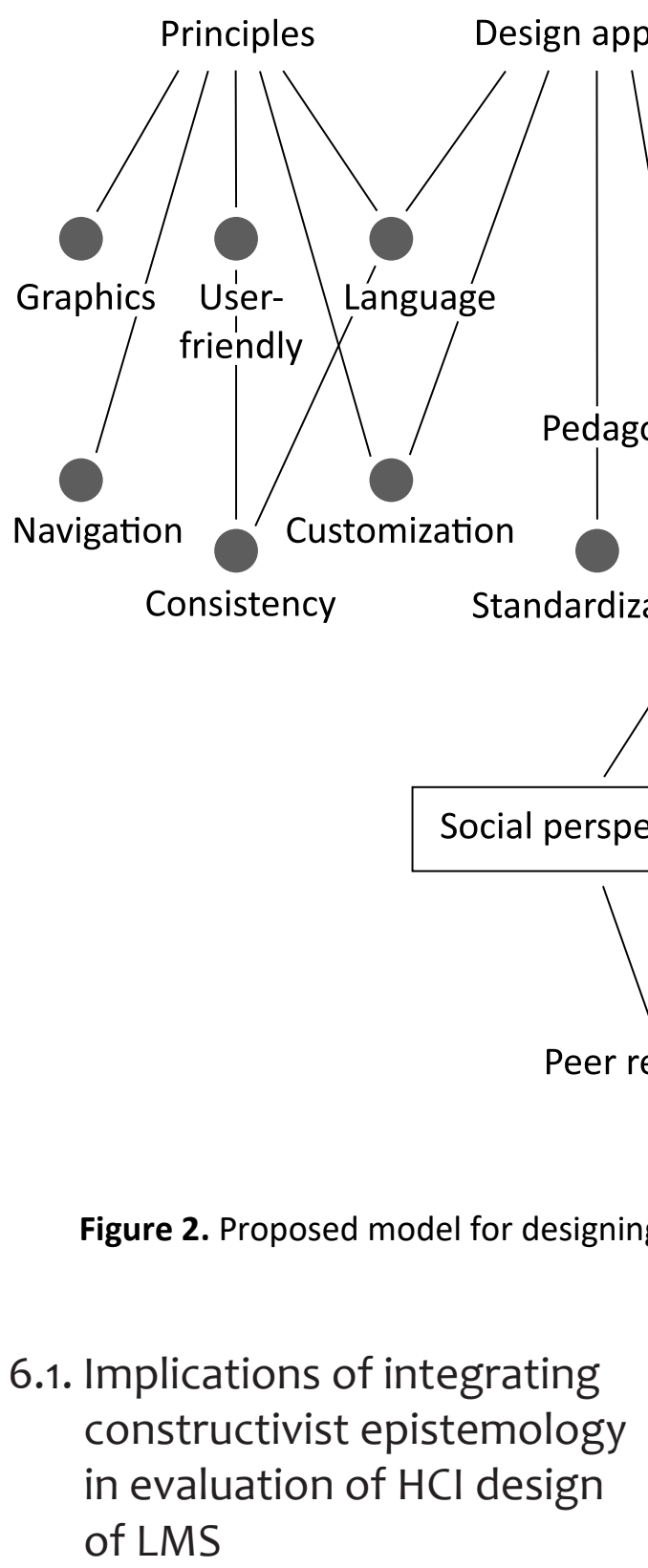

The evaluation of the LMS has shown the importance of designers incorporating all aspects that are considered as important by the users, as well as going a step further to include the emerging trends so as to create a superior product. Designers are to incorporate the preferred educational philosophy of the institution, to adhere to a variety of $\mathrm{HCI}$ design principles, as

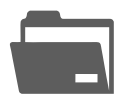

(3) Constructivism

(4) Real

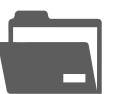

Environment

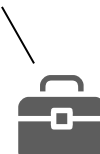

Computer-

mediated communication tools

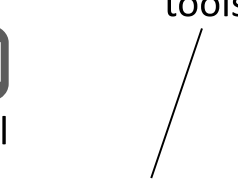

Synchronous
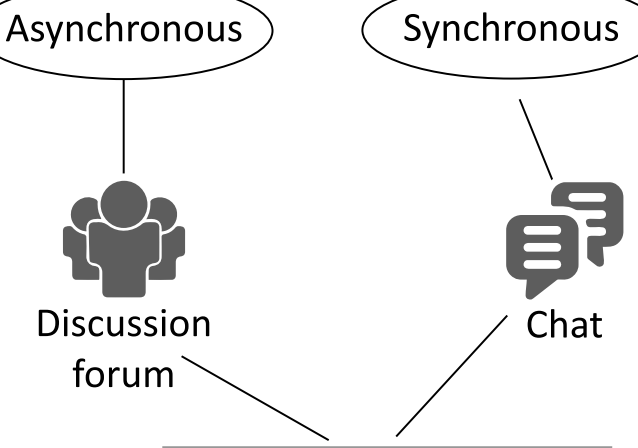

SOCIAL PERSPECTIVE

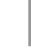




\section{CONCLUSION}

Based on the findings, a number of key requirements are identified for integrating constructivist epistemology in the evaluation of HCI design of LMS as follows:

- the design of the LMS allowed for the integration of a variety of tasks and activities;

- the design of the LMS provided opportunity for learners to use and engage using a variety of digital media and applications such as videos, audios, text, and a variety of other presentation applications;

- the design of the LMS provided opportunity for collaboration, interaction and reflection using a variety of communication tools both asynchronous and synchronous;

- the design of the LMS provided opportunity for integration and application across different subject areas as seen with the biology and digital media students who used the system effortlessly;

- the design of the LMS provided opportunity for seamless integration with the existing systems within the educational institutions so that to there was no duplication of resources;

- the design of the LMS provided opportunity for seamlessly integrating assessment into the teaching and learning process; and

- the design of the LMS allows for both virtual, face interactions, activities, competing, and considers issues of diversity and accessibility factors;

- the users' perception was that the LMS offered an increased access to learning resources;

- the users were reasonably satisfied with the use of LMS in teaching and learning;

- the social constructivist nature of the LMS provided a context for REAL activities and assessment to take place;

- the use of graphics, and inability to customize some of the aspects of the LMS was highlighted. It is also important that the LMS should move with the emerging trends. The users would like to have a system that is easy to customise in a variety of ways such as the themes, colors and icons and in overall design of LMS;

- the HCI design principles were well incorporated in terms of transparency in the language and syntax is vital, in the use of appropriate graphics and downloads and icons. The LMS provided with a platform with CMC tools that enhanced interaction and collaboration was important. Overall, the LMS was consistent in all aspects, customization ability, strong navigation and strong learning and teaching tools were offered are all important elements for a constructivist use of LMS.

\section{RECOMMENDATIONS}

On the basis of this study, the authors propose that it seems reasonable to draw several recommendations to help improve the quality of integrating constructivist epistemology in the evaluation of HCI design of LMS.

- The research found that more tools and elements should be made available at the users' disposal (see Tables 5 and 6). 
- Some users would like to have more control and autonomy in terms of customising the LMS to fit their teaching and learning needs.

- Some of the users would like to see more integration of the LMS with social networks, which are powerful indispensable tools for teaching and learning.

- The users would like to have autonomy over the graphics so that they do not interfere with the learning process. The purpose of graphics and icons should be determined before incorporating them into the LMS to serve a valid purpose of enhancing memorability but not to hinder teaching and learning.

- The LMS should allow users to customise a variety of icons and design of the system to cater for their individual needs.

- The LMS should provide for ability to integrate with emerging social media trends without having to update the system entirety.

The new possibilities offered by the use of LMS can help to revolutionize and support learners in an efficient way.

\section{REFERENCES}

1. Alexander, J. (1999). Collaborative design, constructivist learning, information technology immersion, and electronic communities: A case study. Interpersonal Computing and Technology, 7(1/2).

2. Amiel, T., \& Herrington, J. (2012). Authentic tasks online: Two experiences. In Informed Design of Educational Technologies in Higher Education: Enhanced learning and teaching, Information Science Reference (pp. 152-165). Taylor Francis.

3. Ashford-Rowe, K., Herrington, J., \& Brown, C. (2014). Establishing the critical elements that determine authentic assessment. Assessment and Evaluation in Higher Education, 39(2), 205-222.

4. Athanases S. Z., \& Oliveira LCD (2014). Scaffolding versus Routine Support for Latina/o Youth in an Urban School: Tensions in Building toward Disciplinary Literacy. Journal of Literacy Research, 46, 263-299.

5. Austin, B. (2001). Web page design: A site better than the rest in easy steps. Computer step, Austin.
6. Brickell, G., \& Herrington, J. (2008). Authentic field experiences: The design of complex web-based tasks. UCFV Research Review, 1(3), 36-42.

7. Bruner, J. (1990). Acts of meaning. Cambridge, MA: Harvard University Press.

8. Clark, R. (1994). Media will never influence learning. Educational Technology, 42(2), 21-29.

9. Cetin-Dindar, A. (2016). Student Motivation in Constructivist Learning Environment. Eurasia Journal of Mathematics, Science \& Technology Education, 12(2), 233-247.

10. Creswell, J. W. (2015). Research design: Qualitative, Quantitative and Mixed Methods Approaches (3rd ed.). London: Sage.

11. Creswell, J. W., \& Plano-Clark, L. V. (2011). Designing and conducting mixed methods research (2nd ed.). California: SAGE.

12. Dagar, V, Yadav, A. (2016). Constructivism: A Paradigm for Teaching and Learning. Arts Social Science Journal, 7, 200. https://doi. org/10.4172/2151-6200.1000200
13. Dalsgaard, C. (2014). Social software: E-learning beyond learning management systems. EURODL European Journal of Open, Distance and E-learning, 1-7.

14. Dix. A. (2016). Human Computer Interaction, foundations and new paradigms. Journal of Visual Languages and Computing, special issue in Honour of Stefano Levialdi (in press). https://doi.org/10.1016/j. jvlc.2016.04.001 Retrieved from http://www.hcibook.com/alan/ papers/

15. JVLC-2016-HCI-FNP/Edutechnica (2014). LMS Data - The First Year Update. Retrieved from http:// edutechnica.com/2014/09/23/ lms-data-the-first-year-update/ (accessed on 09.01.2017).

16. Ellis, R. A., \& Calvo, R. A. (2007). Minimum Indicators to Assure Quality of LMS-supported Blended Learning. Educational Technology \& Society, 10(2), 60-70.

17. Fosnot, C. (1996). Constructivism: theory, perspectives, and practice. New York, Teachers College, Columbia University.

18. Gachie, E. W. (2003). Evaluation of a new online learning resource: The 
Human Computer Interface Design Open Learning System. Durban: University of Kwazulu-Natal.

19. Gachie, W. E., \& Govender, D. W. (2015). Integrating digital media technologies in the form of learning management systems for an enhanced learning and teaching environment. Journal of Education, 1-30.

20. Green, C. K. (2013). Campus IT Officers Affirm the Instructional Integration of IT as Their Top Priority, Offer Mixed Reviews on IT Effectiveness and Outsourcing for Online Education. The National Survey of Computing and Information Technology, 35-70.

21. Herrington, J., Reeves, T., \& Oliver, R. (2014). A guide to authentic e-learning. Routledge, London.

22. Ivankova, N. V., Creswell, J. W., \& Plano Clark, V. L. (2007). Foundations and approaches to mixed methods research. Maree, K. (Ed.), First steps in research. Van Schaik, Pretoria.

23. Jonassen, D., Peck, K., \& Wilson, B. (1999). Learning with technology: A constructivist perspective. Merill, New Jersey.

24. Liebowitz, J., \& Frank, M. (2016). Knowledge Management and E-Learning. New York: CRC Press.

25. Makewa, L. N., Kuboja, J. M., Yango, M., \& Ngussa, B. M. (2014). ICT-integration in higher education and student behavioral change: Observations at University of Arusha, Tanzania. American Journal of Educational Research, 2(11A), 30-38. https:// doi.org/10.12691/education2-11A-5

26. Mathewson, T. G. (2015). Kadenze follows up arts-focused MOOC platform with LMS. New York: Education Dive.

27. Marsh, D., \& Storker G. (1995). Theory and methods in political science. Proceedings of ED-MEDIA 2003 World
Conference on Educational Multimedia, Hypermedia and Telecommunication, Honolulu, Hawaii, USA, June 23-28, 2003.

28. McMillan, J. H., \& Schumacher, S. (2011). Research in Education: Evidence-Based Inquiry (7th ed.). Boston: Pearson.

29. Moore, M., \& Thompson, M. (2015). The effects of distance learning: A summary of literature. The American Center for the Study of Distance Education, University Park, Pa.

30. Nielsen, J. (2000). Designing web usability. New Riders Publishing, Indiana.

31. Nielsen, J. (2013). Users pagination preferences and 'view-all'. Retrieved from http:// www.nngroup.com/articles/ item-list-view-all/ (accessed on 27 November. 2013).

32. Onwuegbuzie, A. J. (2014). Mixed analysis techniques: Qualitative dominant mixed analysis techniques. Workshop presented to faculty on behalf of the Organization for Social Science Research in Eastern and Southern Africa (OSSREA). Dar Es Selaam, Tanzania: OSSREA.

33. Onwuegbuzie, A. J., \& Benge, C. L. (2014). Standards and guidelines for conducting, reporting, and publishing quantitative, qualitative, and mixed methods research studies. Workshop presented to faculty and students at the University of West Indies (pp. 1-10). Trinidad and Tobago: University of West Indies.

34. Oulasvirta, A., \& Hornbæk, K. (2016). HCI Research as Problem-Solving. ACM Journal, 1-13. http://dx.doi. org/10.1145/2858036.2858283

35. Oxagile (2016, April 08). History and Trends of Learning Management System [Infographic]. Retrieved from http://www. oxagile.com/company/blog/ history-and-trends-of-learningmanagement-system-infographics/
36. Reeves, T., Herrington, J., \& Oliver, R. (2008). Design research: A better approach to improving online learning. In The E-Learning Handbook: Past Promises, Present Challenges, Pfeiffer (pp. 463-480).

37. Software Advice (2015). Learning Management Systems UserView. New York: Software Advice Inc. Retrieved from http://www. softwareadvice.com/hr/userview/ lms-report-2015/

38. Stone, D., \& Zheng, G. (2015). Learning Management Systems in a Changing Environment. In D. Stone, \& G. Zheng, Handbook of Research on Education and Technology in a Changing Society (pp. 60-79). New York: IGI Global.

39. Tognazzini, B. (2014). First principles of interaction design (revised and expanded). Retrieved from http://www. asktog.com/basics/firstPrinciples html (accessed on November 14, 2015).

40. Tuckman, B. (1979). Analysing and designing educational research. Harcourt Brace Jovanovich, New York.

41. Tuckman, B. W., \& Monetti, D. M. (2011). Educational Psychology (International Edition). Wadsworth Cengage Learning, Florida, USA.

42. Vassiliou, Y. (1982). Human factors and interactive computer systems. N. J. Ablex Publishing Corporation, Norwood.

43. Vygotsky, L. (1962). Thought and language. Cambridge, Mass: MIT Press.

44. Vygotsky, L. (1978). Mind in society: The development of higher psychological processes. Cambridge MA: Harvard University Press.

45. Young, M. (1993). Instructional design for situated learning. Educational Technology Research and Development, 41, 43-58. 